Abstracta Iranica Abstracta Iranica

Revue bibliographique pour le domaine irano-aryen

Volume 26 | 2005

Comptes rendus des publications de 2003

\title{
«Les jarres de l'époque Perse du site Bey 010 ». Archaeology \& History in Lebanon 17, (Spring 2003), pp. 80-94.
}

\section{Astrid Nunn}

\section{(2) OpenEdition}

Journals

Édition électronique

URL : http://journals.openedition.org/abstractairanica/3340

DOI : 10.4000/abstractairanica.3340

ISSN : 1961-960X

Éditeur :

CNRS (UMR 7528 Mondes iraniens et indiens), Éditions de l'IFRI

Édition imprimée

Date de publication : 15 mai 2005

ISSN : 0240-8910

Référence électronique

Astrid Nunn, « «Les jarres de l'époque Perse du site Bey 010 ». Archaeology \& History in Lebanon 17, (Spring 2003), pp. 80-94. », Abstracta Iranica [En ligne], Volume 26 | 2005, document 110, mis en ligne le 08 décembre 2005, consulté le 25 septembre 2020. URL : http://journals.openedition.org/ abstractairanica/3340 ; DOI : https://doi.org/10.4000/abstractairanica.3340

Ce document a été généré automatiquement le 25 septembre 2020.

Tous droits réservés 


\section{«Les jarres de l'époque Perse du site Bey 010 ». Archaeology \& History in Lebanon 17, (Spring 2003), pp. 80-94.}

\section{Astrid Nunn}

Le seul bénéfice de la guerre au Liban est d'avoir rendu possible les fouilles archéologiques en plein centre de Beyrouth (cf. Abs. Ir. 23, 2000, c.r. n ${ }^{\circ}$ 81). Le volume 17 de la très bonne revue du Musée National de Beyrouth est consacré aux amphores. Cet article nous présente les jarres trouvées de 1994 à 1996 sur le site Bey 010. L'A. a divisé le matériel en trois grandes catégories selon leur forme. Ces jarres dans lesquelles on transportait vraisemblablement de l'huile d'olive et du vin sont un indice de l'importance commerciale du Beyrouth achéménide. Ni la question du lieu de fabrication ni celle du lieu de remplissage ne sont résolues.

\section{INDEX}

Thèmes : 3.2.2. Pré-Achéménides et Achéménides

\section{AUTEURS}

ASTRID NUNN

Université de Munich 